J Math Chem (2008) 43:1286

DOI 10.1007/s10910-007-9311-1

ERRATUM

\title{
On the chirality of torus curves and knots
}

\section{Georges H. Wagnière}

Published online: 21 September 2007

(C) Springer Science+Business Media, LLC 2007

Erratum to: J Math Chem (2007) 41(1):27-31

DOI 10.1007/s10910-006-9086-9

Reference [17] should be replaced by:

A. Weis, 3ème Cycle Lectures, Link-Address, http://www.unifr.ch/physics/frap/. See in particular, C. E. Wieman, cited in Lecture 3.

The online version of the original article can be found under doi:10.1007/s10910-006-9086-9.

G. H. Wagniére $(\bowtie)$

Institute of Physical Chemistry, University of Zurich, Winterthurerstr. 190, 8057 Zurich, Switzerland e-mail: wagniere@pci.unizh.ch 